\title{
Sexual Harassment in the Workplace: Selected Court Cases and New Legal Provisions in Malaysia
}

\author{
Kamal Halili Hassan ${ }^{1} \&$ Yee Zing Lee ${ }^{1}$ \\ ${ }^{1}$ Universiti Kebangsaan Malaysia, Malaysia \\ Correspondence: Kamal Halili Hassan, Universiti Kebangsaan Malaysia, Malaysia. E-mail: \\ kamalhalili60@gmail.com
}

Received: August 16, 2013

Accepted: April 21, 2015 Online Published: June 13, 2015

doi:10.5539/ass.v11n16p9

URL: http://dx.doi.org/10.5539/ass.v11n16p9

\begin{abstract}
This paper examines the new legal provisions on sexual harassment in the workplace in Malaysia. Prior to the enactment of the new provisions into the Employment Act 1955, the guidelines for sexual harassment were in the form of a Code of Practices. An employee could only obtain legal redress from the courts on the grounds of constructive dismissal after resigning. The employee concerned could also lodge a police report, but the criminal punishment imposed on the offender did not include compensation for loss suffered by the employee. In addition, there was no clear legal redress protecting the employee suffering from sexual harassment while still on the job. Recognizing these inadequacies, the Malaysian government amended the Employment Act 1955 in 2012 by introducing Part XVA on sexual harassment. Results of sexual harassment cases decided by the Industrial Court have been mixed favoring both the dismissed employees as well as employers. The research method adopted in this paper is legal analysis.
\end{abstract}

Keywords: Malaysia, law, sexual harassment, employees, employer

\section{Introduction}

The traditional view that women should only confine themselves to house-chores is no longer tenable in the reality of today's world (Voydanoff, 1987). Their contributions to the workforce and the economy are extremely vital to the development of a country. However, involvement in the workforce has exposed women to sexual harassment in their workplaces (Roger, 2012; Welsh, 1999). Sexual harassment is a universal issue and has increased considerably during the last two decades. However, the understanding of sexual harassment in workplaces is still not clear and is at best 'sketchy' (Laxman et al., 2013; Mane, 2002; Margaret, 2001). Research has demonstrated that approximately $50 \%$ of women in any particular research sample have experienced unwanted and offensive sex-related behaviors at work places (Magley et al., 1999).

All forms of sexual harassment in workplaces are unwelcome and unwanted. Sexual harassment in the workplace arises when the employer uses his position in the working area to sexually harass his subordinates. Since places of employment are 'home' for more than half of employees' lifetimes in terms of total hours spent, it is important to create a pleasant and conducive workplace for both male and female employees. Sexual harassment is said to be related to the concept of the liberties and equality of an individual. Article 5(1) of the Federal Constitution of Malaysia states that no person shall be deprived of his life or personal liberty saves in accordance with the law.

This judicial pronouncement is echoed in Lembaga Tatatertib Perkhidmatan Awam Hospital Besar Pulau Pinang and Anor v. Utra Badi K Perumal [2000] 3 MLJ 281, in which Gopal Sri Ram JCA stated that depriving a person of his reputation amounts to deprivation of 'life' within the meaning under Article 5(1) of the Federal Constitution. Since the reputation of a person is protected by the Federal Constitution, the violation of this right should allow the claimant to receive non-pecuniary compensation. Sexual harassment deprives victims of their liberty and hence violates their rights. Article 8(1) of the Federal Constitution states that all persons are equal before the law and entitled to the equal protection of the law. Hence based on this provision, sexual harassment is prohibited.

Sexual harassment also results in the violation of the fundamental rights in gender equality and the right to liberty and life as enshrined in the Federal Constitution. Since sexual harassment involves the right and liberty of 
an individual, consciousness of the concept and effects of sexual harassment is crucial. At the same time, women need laws that will provide them with complete protection from sexual harassment (Fitzgerald \& Ormerod, 1991; Francis, 1999; Raymond, 2003).

\section{Methodology}

This study is based primarily on the qualitative method that adopts a critical analysis approach of the legislation. Qualitative research in law refers to any new, thorough, systematic, investigative, or legal analysis. Its aim is to explore, revise, add value, and improve the concept, theory, principles, and application of law. In other words, the research adopts the method of legalistic analysis that emphasizes on legal problems and issues. Using the content analysis technique, this research aims to resolve a problematic situation by identifying the elements that constitute the problems and the regulations relating to them.

Legal research relies on primary and secondary data with the former referring to legislation, parliamentary hansards, and court cases from Malaysia and foreign countries. Cases decided by courts are primary documents in legal research. In this study, we have adopted court cases for use as examples to explore sexual harassment in the work place. The cases illustrate the judicial thinking and reasoning in sexual harassment cases. In addition, new legal provisions pertaining to sexual harassment such as the Employment Act 1955 are also discussed. Cases and new legislation and the criticism on them are the findings of this research which does not rely solely on a review of the literature.

For this study, the authors have selected Industrial Court cases of Malaysia decided from 2008 to 2011. Of course there are other cases of sexual harassment decided by this court before 2008 and also after 2011. However, these cases are obtained as sampling as they represent different facts of sexual harassment and different decisions made on those facts. The Industrial Court is a specialized court hearing disputes on employer-employee relationship. The Industrial Court derived its power and jurisdiction from the Industrial Relations Act 1967. Decisions of the Industrial Court can be challenged by way of 'judicial review' at the High Court but this article focuses only on the Industrial Court's decisions. The Industrial Court mainly deals with issues of facts whereas the High Court, on application of judicial review, focuses on questions of law. Thus, for this study it is better to obtain sampling from the Industrial Court as the facts of the cases showed how the sexual harassment was committed.

\subsection{Literature Review}

Harassment consists of offensive, abusive, belittling, humiliating, and threatening or intimidating behaviour directed at a person or a group of persons (Shereen, 1994; Vandana, 2009). Asghar Ali Ali Mohamed (2011) defines sexual harassment as unwanted conduct of a sexual nature having the effect of verbal, non-verbal, visual, psychological or physical harassment that might, on reasonable grounds, be perceived by recipients as placing a condition of a sexual nature, or an offence or humiliation, or a threat to their well-being. Jashpal Kaur Bhatt (2007) defines sexual harassment simply as unwanted and unwelcome sexual conduct which leads to a hostile and intimidating work environment. Sexual harassment is an act of "an unwanted intrusion on a woman or women by a man or men, and therefore as 'sexism' or 'sexual politics' under another name" (Michele \& Carmen, 2003; Vandana, 2009), while Stanko (2003) views all violations of women by men in terms of "intimate intrusions".

The emphasis on intrusion and invasion clearly indicates that it is the point of view of the female recipients of male behaviours that are being taken into account. Fitzgerald \& Ormerod (1991) define sexual harassment as comprising the sexualisation of an instrumental relationship through the introduction or imposition of sexist or sexual remarks, requests or requirements in the context of formal power differentials. Harassment could also take place when no such formal differential exists if the behaviours are unwanted by or offensive to women (Vandana, 2009). Sexual harassment can take several forms, such as cat calls, wolf whistles, 'curb crawling', and sexual jokes and comments which result in an offensive feeling in the affected employee (Welsh, 1999). Harassment can be verbal and includes uncomfortable and offensive teasing, joking, questioning, jesting, kidding or making suggestive remarks or sounds, or verbal repartees (Jensen \& Gutek, 1982). Visual harassment includes showing pornographic material, pin-ups, calendars, drawings, photographs of naked and scantily clad women or other sex-based materials, as well as writing sex-based letters (Frazier et al., 1995). Different cultures and values have different perceptions of sexual harassment (Fitzgerald \& Ormerod, 1991).

Most of the literature on sexual harassment derived purely from the social science view and not much from the legal perspective. Legal analysis tends to focus on decisions made by courts which this article intends to delve with. Thus, what is the contribution of cases and legislation discussed below to the present literature on sexual harassment? It is submitted that the decided cases and legislation discussed below suggest that although sexual 
harassment do casually and usually occur at the work place, the burden to prove its existence in courts is not easy. The claimant needs strong evidence to prove such act in the court of law. Furthermore, the civil remedy for the victim is not easily obtained and is not a norm in legal redress. What usually occurs is either the aggressor is dismissed from employment or is charged for criminal offence. The victim is still left without civil remedy, as shown in the cases discussed below.

\section{Finding on Sexual Harassment Cases: Judicial Redress V. Legislative Redress}

Women employees who resign their jobs on grounds of sexual harassment may lodge a complaint with the Industrial Relations Department against her employer on the ground of constructive dismissal via section 20 of the Industrial Relations Act 1967. The burden is on the claimant to prove sexual harassment to the Industrial Court. The following are recent cases on sexual harassment in the workplace as decided by the Industrial Court of Malaysia.

\subsection{Tong Yong Industries Sdn Bhd v. Tan Song Poh - Award No.: 432 of 2011}

The claimant was a general manager in the company and was subsequently dismissed on the following grounds: (i) lowering the morale of the existing staff in the company resulting in the unnecessary resignation of several employees, (ii) giving instructions that resulted in the segregation of staff between departments thereby causing a decrease in overall productivity, (iii) failing to adhere to customers' requirements/instructions, and (iv) sexual harassment. A domestic inquiry was held and the claimant was dismissed without compensation.

The claimant charged that he was dismissed without just cause and excuse. The Industrial Court found that the domestic inquiry held by the company was conducted in violation of the rules of natural justice and that the respondent failed to provide details and particulars of the allegations against the claimant such as the time and place of the alleged offence. Hence the Industrial Court held that the claimant was dismissed without just cause and excuse. The court was of the view that reinstatement of the claimant in this company was not a suitable remedy because of the strained relationship between the two parties and ordered compensation in lieu of reinstatement and back-wages as remedies for the claimant.

\subsection{Mohd Nasir Deraman v Sistem Televisyen Malaysia Berhad (TV3) - Award No.: 480 of 2010}

The claimant was an executive broadcast journalist for TV3 ("the company"). He was accused of sexually harassing a practical trainees of the company, Ong Vincci ("the victim") who alleged that he laid his head on her lap despite her protests and rejection while travelling to Port Dickson to produce a programme. The victim also claimed that the claimant made sucking sounds at her and, while looking at her breasts, asked if he could bite them. The claimant admitted that he laid his head on the lap of the victim and that it was done with the consent of the victim. He also contended that he had the habit of making sucking sounds due to a small hole or space in between his front teeth and that he did not make such sounds with any malicious intention towards the victim. With regard to the utterance of the words "biting of breasts" he said that it was a general joke among them in the car. After perusing the evidence and statements of witnesses, the Industrial Court held that the victim's story was more reliable and corroborated by independent evidence. The court held that, "The Claimant's defence is a bare denial of the wrong doing and a blatant lie and not acceptable at all."

\subsection{Ahmad Ibrahim Dato Seri Mohd Ghazau v. August land Hotel Sdn Bhd - Award No.: 1460 of 2010}

The claimant's employment was terminated on the grounds that he had sexually harassed the cashier in the F\&B Department by touching her lips and smacking her buttocks twice without her will and consent. However, no contemporaneous complaint was made and no substantive evidence of this accusation adduced at trail. As such, the court failed to establish on the balance of probabilities that the claimant's dismissal from employment was with just cause and excuse. The Industrial Court opined that, "A charge of sexual harassment brings upon the once accused the potential prospect of enormous but underserved embarrassment and substantial damage not only to the accused's professional standing but also to his social and personal reputation as well, if perchance the claim is grounded upon mendacious accusations." Since sexual harassment is a very serious accusation it must be corroborated by independent evidence. The Industrial Court awarded the claimant compensation in lieu of reinstatement and back-wages.

\subsection{Khoo Ee Peng v. Galaxy Automation Sdn Bhd - Award No.: 656 of 2009}

The claimant stated that she was constructively dismissed by the respondent company's branch manager after she rejected his sexual advances. The company's reason for her dismissal was that she went on leave without filling in the leave application form. She, on the other hand, claimed that she had been sexually harassed by the manager a number of times, and that she did not lodge a police report over the previous incidents because she was concerned about her self-respect and losing her source of income for her family. She also testified that after 
the incident, her petrol allowance was withdrawn although she was not demoted and she was assigned work she did not want to do. After considering the whole chronology of the case, the Industrial Court ruled that the claimant had successfully proved constructive dismissal against the company and that she did not voluntarily resign from her employment.

As noticed from the above ruling, the Industrial Court considered the chain of events before concluding constructive dismissal of the employee. The court ordered the claimant to be reinstated to her former position without any loss of seniority because the branch manager had resigned from the company and she would not have to endure further sexual harassment from him in the workplace.

\subsection{Encik Edwin Michael Jalleh v Freescale Semiconductor Malaysia Sdn Bhd - Award No.: 210 of 2008}

This was a case of being dismissed by a company without just cause and excuse. The claimant was a Senior Manufacturing Supervisor at an electronics factory owned by the company. He was dismissed for sexually harassing a female employee of the company by deliberately touching/patting/smacking her buttocks. The company contended that the misconduct committed by the claimant fell under the category of "inacceptable conduct" of the Disciplinary Policy of the Company. It made reference to the company's Code of Practice for The Prevention and Eradication of Sexual Harassment in the Workplace in establishing whether the act by the claimant constituted "sexual harassment". The claimant, on the other hand, claimed that he had been victimized by the Manufacturing Manager of the company who held a grudge against him which led to his dismissal.

The Industrial Court held that the very act of the claimant slapping the buttocks of the female employee was an act of sexual harassment, although it deemed that the punishment of dismissal a bit too harsh. The court took into account the fact that the act occurred in an "open area", "the victim's flesh was not violated by the claimant as it was protected by layers of cloth" and that there was "...no further danger to her as she was surrounded by her colleagues" in deciding that the punishment of dismissal was too harsh in the circumstances and that it was without just cause and excuse. It awarded the claimant compensation in lieu of reinstatement but also reduced it $30 \%$ for his contributory misconduct.

It can be seen from this case that although sexual harassment is a serious misconduct, the Industrial Court would not necessarily sanction dismissal as a punishment if it deems it too harsh on the claimant. However, the court acknowledged the contributory misconduct of the claimant and ordered the compensation to be scaled down.

\subsection{Legislative Redress}

The Employment (Amendment) Bill 2011("Bill") (DR 15/2011) was tabled in Parliament and passed in 2012. The Bill also introduced Part XVA titled Sexual Harassment which makes sexual harassment at the workplace illegal, regardless of the wage level of the employee. The definition of "Sexual harassment" is also inserted in section 2 of the Act and means:

“....any unwanted conduct of a sexual nature, whether verbal, visual, gestural or physical, which is directed at a person and is either offensive, humiliating or a threat to his/her well-being, which occurs during or in the course of employment."

Section $81 \mathrm{~B}$ of the Act requires an employer to conduct an inquiry into any complaint of sexual harassment in the workplace. Where an employer refuses to do so, the employer must inform the employee of his reasons for refusal and the aggrieved employee may refer the matter to the Director General of Labour. This section also notes that the employer may refuse to inquire into any complaints of sexual harassment if the complaint of sexual harassment has previously been inquired into and no sexual harassment has been proven, or if the employer is of the opinion that the complaint of sexual harassment is frivolous, vexatious or not made in good faith. The individual found guilty of sexual harassment may be dismissed without notice, demoted or penalized with a lesser punishment, e.g., suspension without pay for a period of up to two weeks.

This is provided under Section $81 \mathrm{C}$ of the Act which is similar to section 14(2) of the Act. In a situation where the complaint is lodged against an employer, the Director General will conduct an inquiry and where the individual engaging in such conduct is not an employee, the individual may be brought before a disciplinary authority which he is subject to. The procedure for the Director General in handling the complaints of sexual harassment is stated under Section $81 \mathrm{D}$ of the Act. If sexual harassment is proven by the Director General, the complainant may terminate his contract of service. According to Section $81 \mathrm{E}$ of the Act, the complainant is also entitled to wages, termination benefits and indemnity provided under the Employment Act.

An employer who fails to inquire into the complaints of sexual harassment, inform the complainant of the reason of the refusal, inquire into the complaints as directed by the Director General or fails to submit a report of inquiry into sexual harassment to the Director General commits an offence under Section 81F. An employer who 
commits an offence of sexual harassment shall be liable to a fine not exceeding ten thousand ringgit. The introduction of provisions on sexual offences into the Employment Act 1955 is commendable as it now has legal force. The new amendment has brought new dimension into labor relations where the protection of sexual harassment at the workplace is clearly spelt out. It provides criminal sanctions on wrongdoings where employers are legally bound to initiate action once a complaint is made. This is considered a new dawn in Malaysian labour relations particularly for women employees ( $\mathrm{Ng}$ et al., 2003).

There has been no court cases so far derived from this new amendment. This is because application for remedy for employees dismissed due to sexual harassment is still covered under the current section 20 of the Industrial Relations Act 1967. This new amendment does not give the right to file a dismissal case in court but to compel the employer to take a domestic action against the aggressor.

\section{Conclusion}

In case No. 3.1, the court decided that the employee's dismissal on the allegation of sexual harassment of her female staff was bad in law. In case No. 3.2, the court decided that the employee's dismissal because of his sexual harassment act was correct. In case No. 3.3, the court stated that no substantive evident was adduced to show that the male employer sexually harassed his female staff, and deemed the dismissal was bad. In case No. 3.4, the female employee's claim for constructive dismissal on the grounds of being sexually harassed by her superior was successful. In case No. 3.5, though sexual harassment is considered a serious misconduct, the Industrial Court did not order a dismissal as a punishment since it was of the opinion that it was too harsh on the claimant.

The above cases demonstrate that any allegation of sexual harassment requires concrete evidence to support it. The onus to prove is on the accuser and it is not an easy burden to discharge. That is the reason why Parliament enacted the amendment in the Employment Act 1955 to allow cases of sexual harassment to be first dealt with at the workplace. Only after the employer fails to discharge its duty in taking action at the workplace can a complainant proceed with a legal suit under section 20 of the Industrial Relations Act 1967.

The impact of sexual harassment is serious and can cause much physical and physiological distress to employees and unnecessary tension at the workplace. There is a need for safe and conducive working environments for working women. Prior to the amendments to the Employment Act 1955, the Malaysian legal system did not provide clear protection to workers from sexual harassment. The current Employment (Amendment) Act 2012 incorporates important provisions in Malaysian law against sexual harassment. The act's Part XVA is a strong deterrent to sexual harassment at the workplace by making it illegal regardless of the wage level of the employee. The new amendment states that employers must take action against any employee accused of sexual harassment based on any complaint made by a victim. Failure to institute the action will be considered an offence committed by the employer.

The Malaysian legal system offers limited redress for sexual harassment complaints whether at the criminal, labour, or administrative level. There is a need for the authorities to consider a separate act specifically to deal with sexual harassment. While there is nothing that can guarantee protection from sexual harassment including specific legislation, a specific and comprehensive act which deals directly with such offences would contribute much to reduce such incidents and is the way forward to promoting a more conducive workplace.

\section{Acknowledgements}

The authors would like to record their appreciation to the Universiti Kebangsaan Malaysia, Malaysia for providing research grant Nos. ETP 2013-029.

\section{References}

Achampong, F. (1999). Workplace Sexual Harassment Law: Principles, Landmark Developments, and Framework for Effective Risk Management. Quorum Books.

Ahmad Ibrahim Dato Seri Mohd Ghazau v. Augustland Hotel Sdn Bhd - Award No.: 1460 of 2010.

Bhatt, J. K. (2007). Sexual Harassment in the Workplace-Legal Redress for a Gendered Issue. UITM Law Review, 33-54.

Bingham, S. G. (1994). Conceptualizing Sexual Harassment as Discursive Practice. Praeger Publishers.

Cleveland, J. N., Stockdale, M., Murphy, K. R. (2000). Women and Men in Organizations: Sex and Gender Issues at Work. Lawrence Erlbaum Associates.

Crouch, M. A. (2001). Thinking about Sexual Harassment: A Guide for the Perplexed. Oxford University Press. 
Encik Edwin Michael Jalleh v Freescale Semiconductor Malaysia Sdn Bhd - Award No.: 210 of 2008.

Fitzgerald, L. F., \& Ormerod, A. J. (1991). Perceptions of sexual harassment. Psychology of Women Quarterly, 15(2), 281-294. http://dx.doi.org/10.1111/j.1471-6402.1991.tb00797.x

Frazier, P. A., Cochran, C. C., \& Olson, A. M. (1995). Social science research on lay definitions of sexual harassment. Journal of Social Issues, 51(1), 21-37. http://dx.doi.org/10.1111/j.1540-4560.1995.tb01306.x

Gregory, R. F. (2003). Women and Workplace Discrimination: Overcoming Barriers to Gender Equality. Rutgers University Press.

Hajdin, M. (2002). The Law of Sexual Harassment: A Critique. Susquehanna University Press.

Jensen, I. W., \& Gutek, B. A. (1982). Attributions and assignments of responsibility in sexual harassment. Journal of Social Issues, 38(4), 121-136. http://dx.doi.org/10.1111/j.1540-4560.1982.tb01914.x

Khoo Ee Peng v. Galaxy Automation Sdn Bhd - Award No.: 656 of 2009.

Laxman, L., Som, H. M., Saat, M. M., \& Heng, L. H. (2013). A Study on Sexual Harassment in Small and Medim Enterprises of Malaysia, Vot 71875. Retrieved April 19, 2013, from http://eprints.utm.my/2682/1/71875.pdf

Lembaga Tatatertib Perkhidmatan Awam Hospital Besar Pulau Pinang and Anor v. Utra Badi K Peruma l. (2000). 3 MLJ 281.

Magley, V. J., Hulin, C. L., Fitzgerald, L. F., \& DeNardo, M. (1999). Outcomes of self-labeling sexual harassment. Journal of Applied Psychology, 84, 390-402. http://dx.doi.org/10.1037/0021-9010.84.3.390

Mohamed, A. A. A. (2011). Sexual harassment at the workplace in Malaysia. KL: CLJ publication.

Mohd Nasir Deraman v Sistem Televisyen Malaysia Berhad (TV 3) - Award No.: 480-2010.

Ng, C., Nor, Z. M., \& Abdullah, M. C. (2003). A Pioneering Step: Sexual Harassment and the Code of Practice in Malaysia. Kuala Lumpur: SIRD: 43.

Paludi, M., \& Paludi, C. A. Jr. (2003). Academic and Workplace Sexual Harassment: A Handbook of Cultural, Social Science, Management, and Legal Perspectives. Praeger.

Shuy, R. W. (2012). The Language of Sexual Misconduct Cases. Oxford University Press. http://dx.doi.org/10. 1093/acprof:oso/9780199926961.001.0001

Stanko, E. A. (2003). The Meanings of Violence. London, Routledge.

Tong Yong Industries Sdn Bhd v. Tan Song Poh - Award No.: 432 of 2011.

Vandana. (2009). Sexual Violence against Women: Penal Law and Human Rights Perspectives. New Delhi: LexisNexis Butterworths Wadhwa Nagpur.

Voydanoff, P. (1987). Work and Family Life. England: Saga Publications, Inc.

Welsh, S. (1999). Gender and sexual harassment. Annual. Rev. Social, 25, 169-190. CASES. http://dx.doi.org/10. 1146/annurev.soc.25.1.169

\section{Copyrights}

Copyright for this article is retained by the author(s), with first publication rights granted to the journal.

This is an open-access article distributed under the terms and conditions of the Creative Commons Attribution license (http://creativecommons.org/licenses/by/3.0/). 